\title{
Earthquake effects and insights on fault activity at the Beatrice Cenci cave (Abruzzo, Central Apennines)
}

\author{
Laura Alfonsi* and Francesca Romana Cinti \\ Istituto Nazionale di Geofisica e Vulcanologia, Roma, Italy \\ Article history: received September 21, 2020; accepted May 19, 2021
}

\begin{abstract}
The focus of this study is the analysis of a cave in Central Italy, the Beatrice Cenci cave, in order to point out and constrain evidence of possible past earthquakes and of fault activity in the area. We performed a survey of seismic related damages within the cave. This included the analysis of broken/collapsed speleothems, the recognition of structural collapse, of tilting/growth alteration in the speleothems, and the mapping of fractures, joints and/or faults. To timely set the occurrence of the recognized damage, organic sediments were dated with ${ }^{14} \mathrm{C}$ radiocarbon method. The results merged toward the recognition of two distinct seismic shaking events affecting the cave environment, one older than $30 \mathrm{kyr}$ and another around $7 \mathrm{kyr}$. The deformation observed within the cave led us to the hypothesis that the events of damage were possibly linked to the activity of the regional tectonic lineament that crosses the cave, i.e., the Liri normal fault. The morphology and the evolution of the cave appear controlled by the fault zone. These speleoseismological results provided a new contribution on the knowledge of the past activity of the Liri fault and on the earthquake history of this sector of Central Apennines.
\end{abstract}

Keywords: Speleothems; Earthquakes; Speleoseimology; Tectonic activity; Liri Fault; Central Italy.

\section{Introduction}

We conducted an exploratory speleoseismic analysis of the Beatrice Cenci cave positioned in one of the most seismogenic regions in Italy, which has been struck by medium to large earthquakes in present, historical and prehistoric times [Rovida et al., 2019; Carta Geologica d'Italia 1:50.000, Sheet 367, Tagliacozzo; Figure 1]. The aim was to acquire observation and data related to the paleoearthquakes effects within the cave environment, and define their time of occurrence. In particular, the Beatrice Cenci cave is intersected by a regional lineament, named the Liri fault, and thus potentially offers objective elements to discriminate on the activity of this fault.

The research into speleoseismites includes broken speleothems, fallen stalactites, severed stalagmites, growth anomalies in speleothems, and vault ceiling collapses; it can provide evidence of paleoearthquakes occurrence also at very old time intervals [e.g., Forti and Postpischl, 1984; Kagan et al., 2005, 2017; Braun et al., 2010; Becker et al., 2012; Szczygieł et al., 2021]. This work is the first speleoseismic analysis conducted within the Beatrice Cenci cave, while studies devoted to the reconstruction of paleoearthquakes record have been conducted in caves nearby [i.e. 


\section{Laura Alfonsi et al.}

Grotta dei Cervi at Pietrasecca, Postpischl et al., 1991; Continenza cave at Trasacco, Giraudi and Frezzotti, 1999; Grotta Cola at Petrella Liri, Pace et al., 2020; Figure 1].

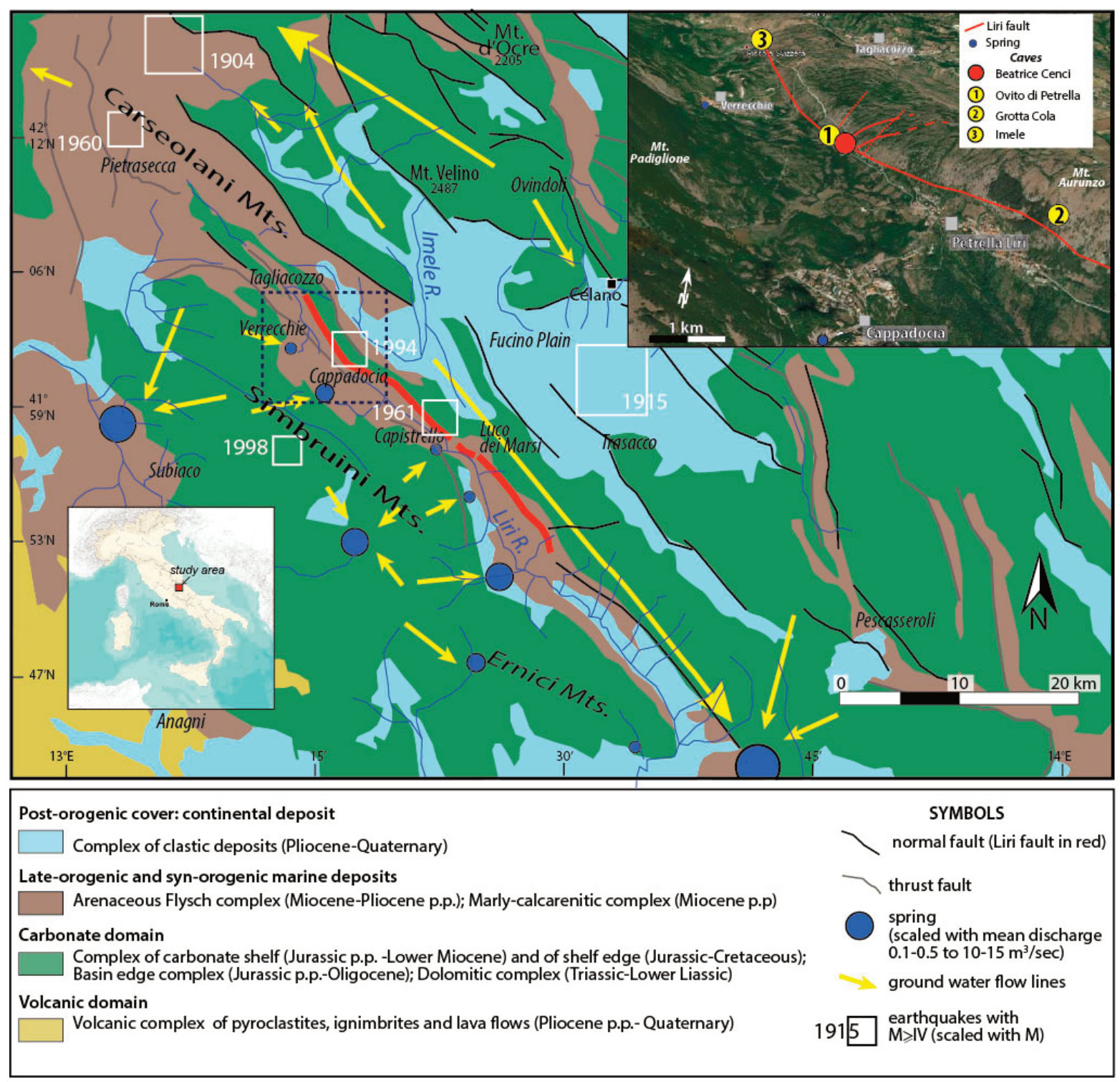

Figure 1. Simplified geological map of the Beatrice Cenci cave region. Major faults are reported from Carta Geologica d'Italia 1:50.000, Sheet 367, Tagliacozzo [Compagnoni et al., 2005; see also Comerci et al., 2013], in red is the Liri fault crossing the study area. Historical earthquakes are from Rovida et al. [2021]. Dashed rectangle includes the area enlarged in the upper right inset. Here, the locations of the Beatrice Cenci cave, the Grotta Cola cave, the swallow holes of Ovito di Petrella and Imele, are reported along with the Liri fault trace and the transversal faults crossing the caves. Springs and groundwater flow lines are from Boni et al. [1988].

The Beatrice Cenci cave (1060 m a.s.1.; lat 42 $01^{\prime} 37^{\prime \prime} 5$, lon $13^{\circ} 16^{\prime} 05^{\prime \prime} 4$; hereinafter referred as Beatrice Cenci) is located in the Abruzzi region, Central Apennines, Italy (Figure 1). The cave belongs to a karst complex developed at the base of the southwestern slope of Mt. Aurunzo (1455 m a.s.l.) between the villages of Petrella Liri and Verrecchie (Figure 1), along the $35 \mathrm{~km}$-long Mts. Carseolani ridge. This ridge borders the local closed endorheic basins of Verrecchie and Petrella Liri developed at the contact of the flysch deposit and the limestone ridge. The karst complex includes the Imele swallow hole (better known as l'Otre; $944 \mathrm{~m}$ a.s.l.) to the Northwest of the Beatrice 
Cenci cave (inset in Figure 1), that collects the waters from the spring of the Imele river located at Verrecchie; the Ovito di Petrella swallow hole (1030 m a.s.l.), a 100 m-deep vertical well that gathers the waters flowing from the local springs on the Mt. Padiglione and the shallow water circulation; Northeast of the Petrella Liri village is located the karst cave of Grotta Cola (1200 m a.s.l.), that is a fossil cave with a large initial chamber and conduits.

The presence of these karst elements at different elevations along the ridge indicates the progressive deepening of the endorheic drainage network. The tectonics had a key role in the evolution of Mt. Aurunzo underground cavities, on their development and life-time. Indeed, all cavities are aligned along the Liri fault trace bordering the southern flank of the Mounts Carseolani ridge (Figures 1, 2) [Carrara et al., 1995; Chiarini et al., 1997; Ciotoli et al., 1993; Montone and Salvini, 1993; Compagnoni et al., 2005], and in detail, the Beatrice Cenci cave is directly crossed by the northern sector of the Liri fault (Tagliacozzo-Capistrello sector, Figure 1). The Liri fault belongs to the network of closely spaced normal faults, NW to NNW trending, SW dipping of the central Apennines region where the seismicity occurs. This fault is a $\sim 50 \mathrm{~km}$ long regional NW-SE striking fault, with a past left-lateral transpressive history reported along its northernmost sector [Montone and Salvini, 1993; Fabbi, 2018 and reference therein], reactivated as an extensional fault [e.g., Serafini and Vittori, 1995; Galadini, 1999]. The survey of He and Rn anomalies in soil gas suggests that this fault is the surface expression of a deep fracture system [Ciotoli et al., 1993].

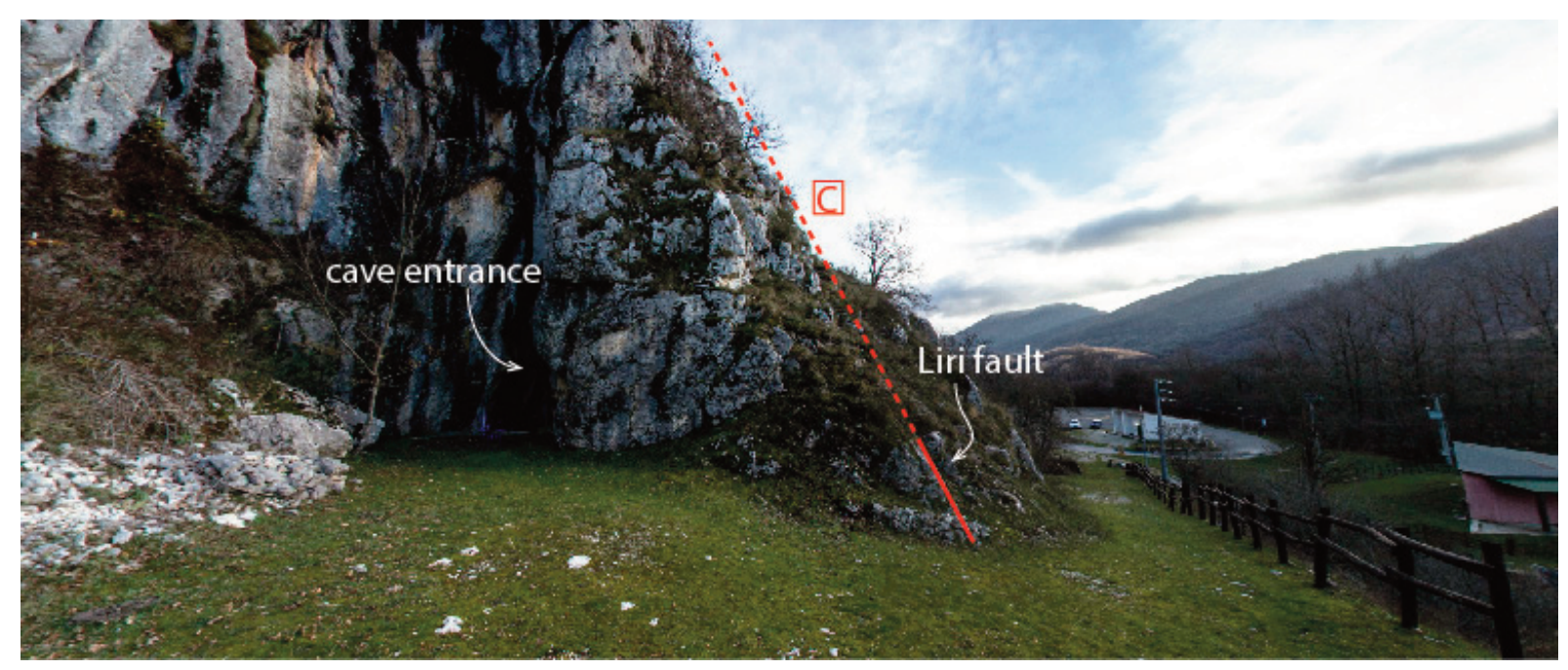

Figure 2. External $\sim 3 \mathrm{~m}$ - wide entrance of the Beatrice Cenci cave, view from Northwest. Red line marks the bedrock plane of the Liri fault referred to as fault $\mathrm{C}$ in the map and sections of Figure 3.

The present activity of the Liri fault is debated; several authors questioned the fault is sealed by middle Pleistocene deposits [e.g. Galadini and Galli, 2000], while others interpret the fault as a secondary active structure probably responsible for part of the extension observed in the GPS data [e.g., Papanikolau et al., 2005; Roberts and Michetti, 2004]. Earthquake recurrence models of the Central Apennines include the Liri fault and assign slip rate to its northern sector lower with respect to the southern one (i.e. 0.1-0.5 mm/yr vs 0.6-1.0 mm) [e.g., Faure Walker et al., 2020; Scotti et al., 2021 and reference therein]. Independent data on the past activity of the Liri fault collected so far are still few, however it is worth noting that the speleoseismic study by Pace et al. [2020] at the nearby Grotta Cola cave highlights coseismic effects occurring in Holocene time, and suggests the Liri fault as the most likely source for the ground shaking recorded in the cave, although the nearby Fucino fault system is not excluded as the potential source of the speleoseismic damage. Being the Beatrice Cenci cave on-fault, our data may represent an advance in revealing the source for the earthquake damage in the caves.

\section{Data: tectonic and earthquake shaking signatures}

The Beatrice Cenci cave was firstly explored and described in 1892 by I.C. Gavini and G. Voltan. 


\section{Laura Alfonsi et al.}

The cave developed close to the ground surface and lies in the downhill flank of the Auronzo ridge, a topographically exposed position; all aspects that have been proven to make this kind of cavities vulnerable to shaking caused by strong earthquakes [Becker et al., 2006]. It is shaped by an initial narrow gallery and two main wide chambers (Figure 3a). It is inferred that the cave was the former swallow hole of the valley water circulation, which nowadays is drained by the close Ovito di Petrella cavity (Figure 1). The water modelled the cave in the past, the actual morphology of chambers, with elliptic galleries, as well as hollows that result from the shaping action of underground waters. Presently, a small lake, not deeper than $50 \mathrm{~cm}$, with seasonal variation, is still existent at the very end of the terminal chamber (Figure 3a). An ephemeral water flow is present only in heavy rainy seasons. The cave is rich in speleothems along with fractures and bedding planes where the dripping is still active. Flowstone and rim-stones are observed in the whole cave. Stalagmites and stalactites of large dimension are concentrated in the second terminal chamber, and almost all of them grew along the fractures and faults crossing the ceiling.

In the first chamber, the active dripping produced stalactites of exiguous size, both in height and width, and the stalagmites are a few centimeters tall. Here, remnants of older speleothems are also observed, although sparse, but broken or cut up. As major remarks, it is evident that the cave is shaped following the direction of the fault lines and the speleothems of the cave are affected by the deformation.

The Beatrice Cenci has been used as a shelter since Neolithic time and traces of frequentation are indicated by rests of wood, iron, and ceramic ancient artifacts [Agostini et al., 1991]. The archaeological settlement was the object of an excavation in the early '90s [Agostini et al., 1991], that at present is badly preserved and marked by a dismantled ditch.

We proceeded with the research in successive steps: geological survey of the cave surroundings, inspection and documentation of damaged cave formations, sampling, ${ }^{14} \mathrm{C}$ dating of soft sediments for the event time constraints, chronological interpretation and determination of specific events.

\subsection{Morphology and orientation of the cave}

The initial descendent gallery is rich in speleothems and it has a triangular cross section: the vault is developed on an evident $230^{\circ}-240^{\circ}$ oriented (azimuth convention), about $50 \mathrm{~m}$ long fault (fault A in Figure 3a; Figure 4a). This continues into the ceiling of the first chamber holding the same direction, reaching as a whole a length of about 100 $m$. This lineament and the sharp vertical southern wall of the first chamber (fault A' in Figure 3a) coincide with the fault traces mapped transversally to the Mt. Aurunzo - Mt. La Difesa ridge (inset in Figure 1).

The second chamber of the cave turns almost $90^{\circ}$, with respect to the entrance, and develops along a $325^{\circ}$ direction (Figure 3a). Two clear fractures cross the entire vault with a direction ranging between $310^{\circ}$ and $315^{\circ}$, for a minimum extent of $100 \mathrm{~m}$, both merging toward the southern conduit of the chamber (fault B in Figure 3a; Figure 4b). In the terminal portion of the chamber, we also infer a subparallel fault bordering the sharp wall in correspondence of which there is a fossil conduit, presently at a higher level with respect to the other (fault B' in Figure 3a; Figure 4b). This latter fault line, as well as fault $\mathrm{B}$, is subparallel to the fault plane observed outside the cave and bordering the ridge slope (fault $\mathrm{C}$ in Figure 3a and Figure 2). The bedrock plane of B' outcrops along the edge of the above road. The position of faults and the cave morphology is sketched in section in Figure 3b. According to our analysis the subparallel faults here depicted are part of the Liri fault zone and, along with local transversal anti-Apennine elements (fault A and A' in Figure 3a), influenced the development of the cave. The high angle NW-SE fault planes in the surrounding of the cave area show kinematic indicators, as left-lateral and dip-slip striae.

\subsection{Tilting of stalagmites}

This feature was observed in situ in the second and deepest cave chamber (zone 1 in Figure 3a). Here, closely spaced tilted large size stalagmites (up to 2,5 $\mathrm{m}$ high and max diameter of $1 \mathrm{~m}$ ) form a $20 \mathrm{~m}$ long alignment, along the $330^{\circ}-340^{\circ}$ direction. The tilting observed is constantly West-Southwest and varies from $10^{\circ}$ to a maximum degree of $18^{\circ}$ (Figures 4c, 4d). Younger stalagmites with an undisturbed vertical growth formed on top of the tilted elements (Figure 4c). At this location, the formation of the concretions originates by dripping from the fault crossing the vault (Figure 4b, c, d; fault B in Figure 3a). It is worth noting that the signature of tilting generally reflects a near 

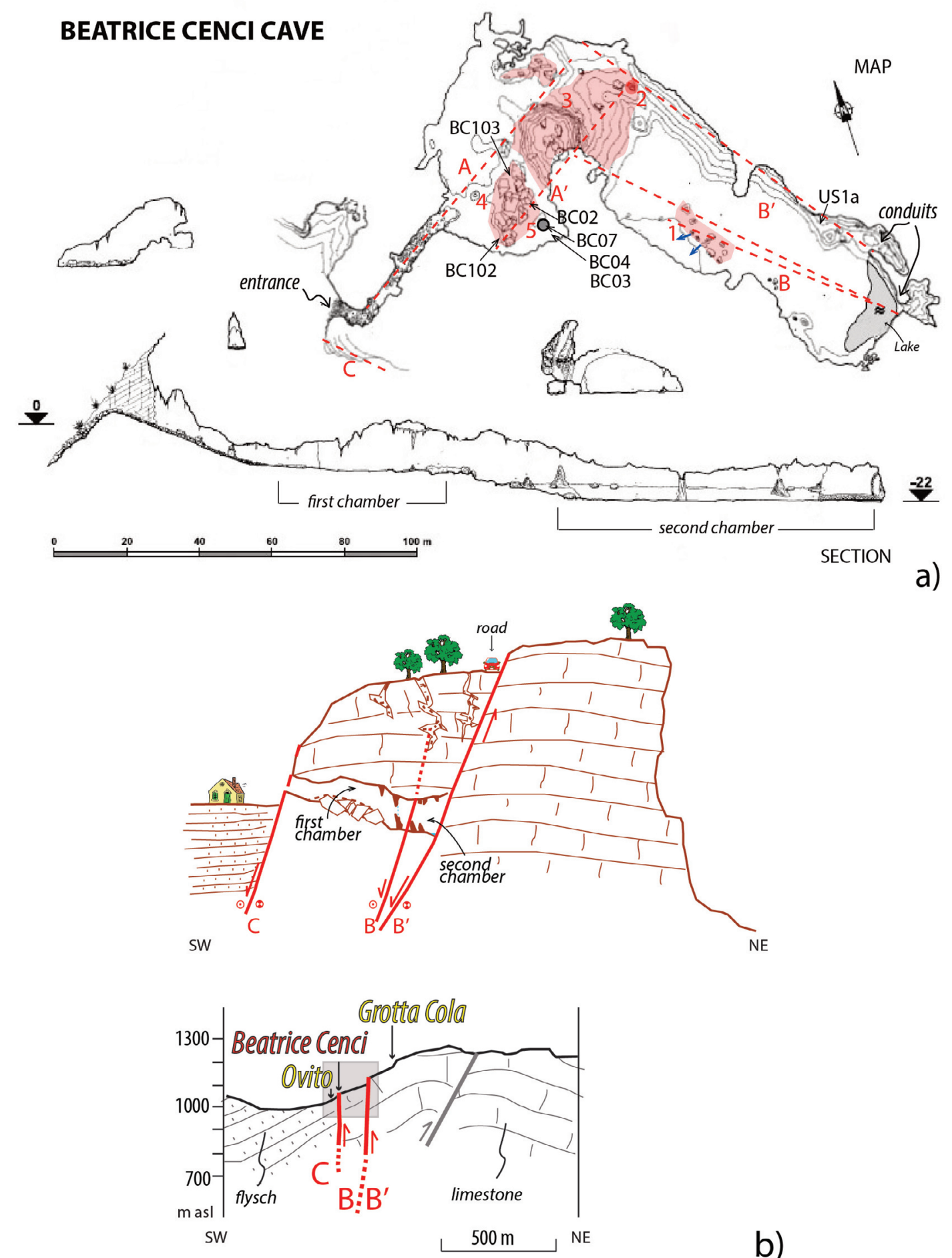

b)

Figure 3. a) Map of the Beatrice Cenci cave (modified from Mecchia et al. [2003]). The location of the collected samples for ${ }^{14} \mathrm{C}$ dating is shown. Sample codes as in Table 1. Red dashed lines represent the faults and fractures inferred (this work) crossing the ceiling and the wall of the chambers (see Figures 2 and 4). Faults are marked with red capital letters, as referred in the text and in the figures. Pink areas include zones of collapses and deformation, identified with red numbers, as referred in the text and in figures. Blue arrows show the direction of tilting of the stalagmites in zone 1 (see also Figures $4 \mathrm{c}$ and $4 \mathrm{~d}$ ). b) Schematic section of the faults setting relative to the Beatrice Cenci cave, upper panel not in scale. In the lower panel, the location of the three caves is projected along a sketch of the Mt. Aurunzo slope. Note the different elevation of the Grotta Cola, Ovito di Petrella, and Beatrice Cenci, respectively in the footwall, hanging wall, and within the Liri fault zone (grey square is the area sketched above). Red capital letters identify the faults as in plain view of Figure 3a. 


\section{Laura Alfonsi et al.}

fault-deformation [e.g. Forti and Postpischl, 1984]. More precisely, we observe axis-deviation indicating tilting of stalagmites together with its bedrock [Becker et al., 2006]. Although with some uncertainty, the tilted stalagmites in our cave are positioned on stable consolidated strata and not on soft alluvial sediments.

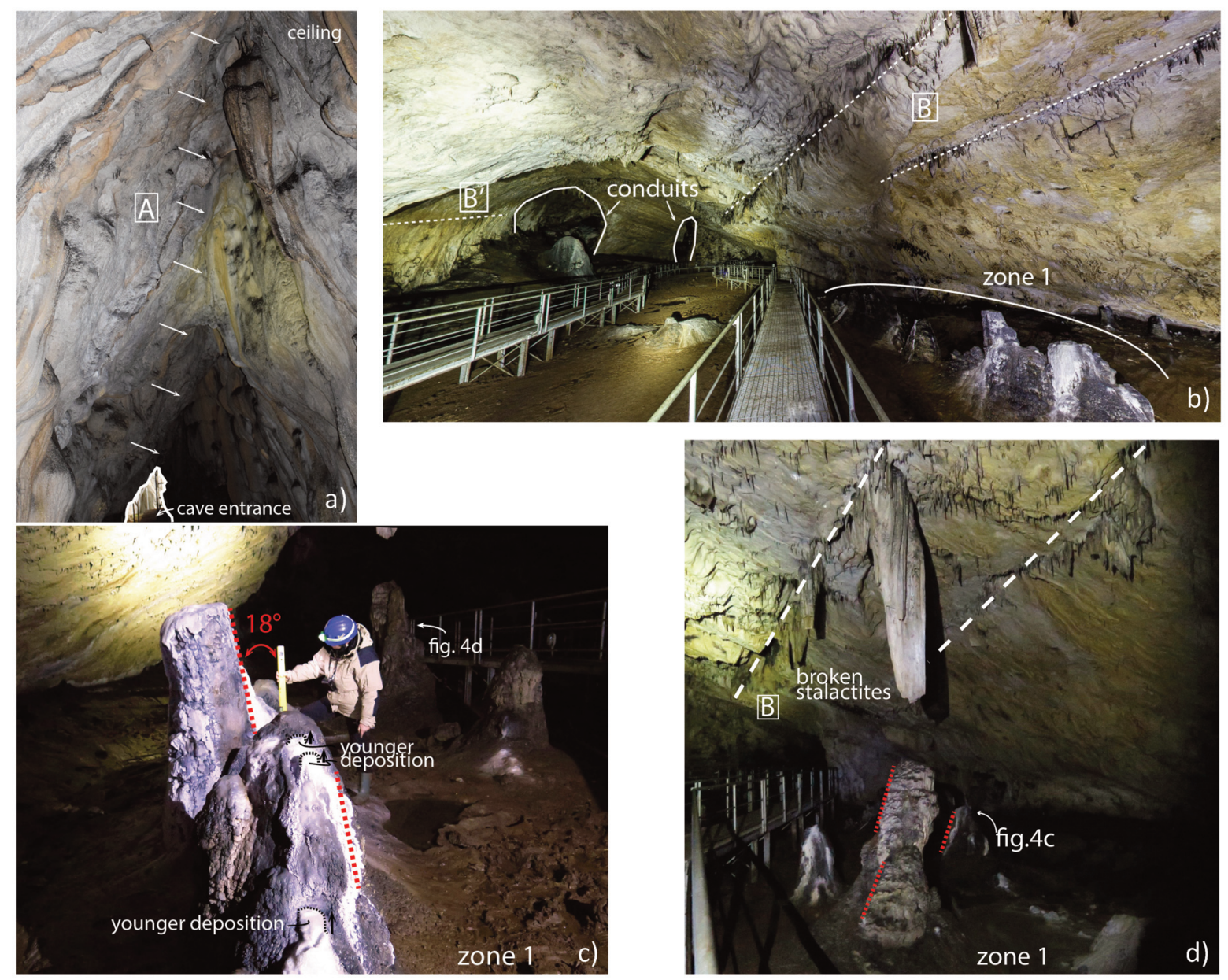

Figure 4. Views of the main tectonic lineaments observed within the cave and deformation surveyed. These are referred to with capital letters and zone numbers, respectively (same as in map of Figure 3a and Table 1): a) initial descendent gallery with a triangular section, the vault developed on an evident fracture (white arrows, fault line A); b) second gallery, view to the Southeast, a fault plane is inferred in the northern wall; converging linear fractures cross the ceiling (white dashed lines, fault lines B-B'), two water conduits developed in their correspondence (see also Figure 3a), the northern is the former at a higher elevation and presently fossil; c) alignment of tilted stalagmites in zone 1 , surveyed below fault B, view to the Northwest (see Figures $4 \mathrm{~b}$ and 4d); regular regrowth on top of these stalagmites, the black arrows representing the vertical axis; d) view to the Southeast of the alignment of the tilted stalagmites in zone 1, developed in coincidence of fault line B (dashed white lines). Along the fractures severed stalactites are hanging from the ceiling.

\subsection{Collapsed limestone ceilings}

Massive vault collapses occupy a large portion of the first chamber of the cave, and it is estimated that about $5 \times 10^{3} \mathrm{~m}^{3}$ of material collapsed. In detail, at the entrance of the chamber large blocks (in the order of meters; zone 4 in Figure 3a) lie on the floor keeping the original limestone bedding (Figure 5a). At this site, it is clear that the thin tabular flowstone (with thickness $\sim 3.5 \mathrm{~cm}$ ) forming the actual pavement of the cave, envelopes undisturbed the 

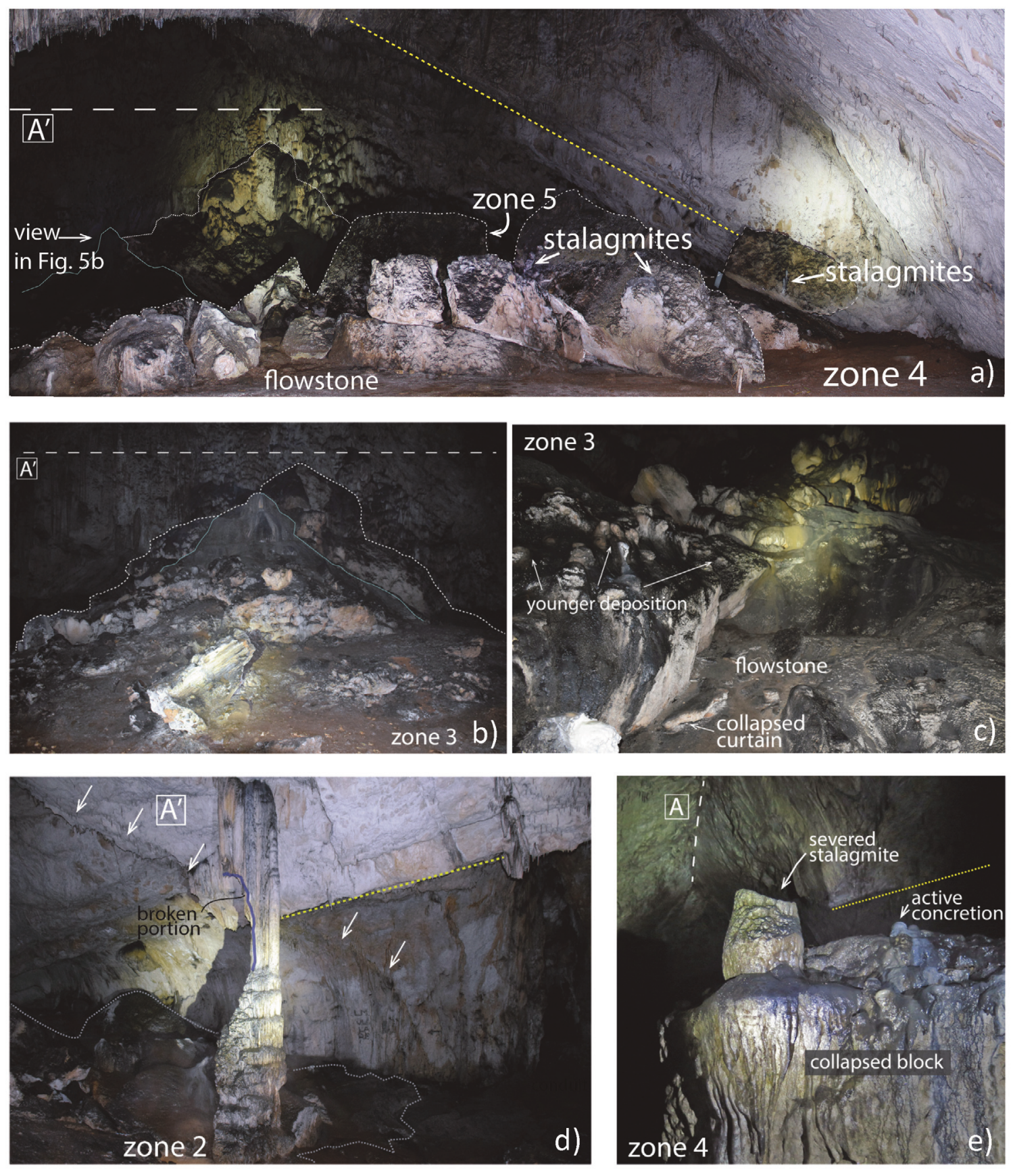

Figure 5. Views of the main tectonic lineaments observed within the cave and deformation surveyed. These are referred to with capital letters and zone numbers, respectively (same as in map of Figure 3a and Table 1): a) massive collapse of the vault in zone 4 in the first chamber, view to the South. Active stalagmites develop on top of the large blocks; b) view to the South of zone 3 at the chambers' junction. The collapsed area occurs along the alignment of fault A' recognized in the vault (white dashed line), small and fragmented boulders form a pile are sealed by concretions becoming the ramp leading to the second and deepest chamber; c) detail of the collapsed area in correspondence of the chambers' junction (view to the Southeast, zone 3). The blocks are draped by flowstone, and new stalagmites form on top; $\mathrm{d}$ ) view of zone 2, a column is damaged in the upper portion (purple line). Vault and wall are cut by a fracture (white arrows) identified as A'. Yellow dashed line outlines the NW dipping limestone bedding. On the floor and in the background are visible the collapsed blocks (contour dotted grey line); e) A large collapsed block in the first room (zone 4), on its. On top there is a big severed stalagmite and freshly formed concretions. Fault line A on the ceiling is traced (dashed white line). Yellow dashed line outlines the NW dipping limestone bedding. 


\section{Laura Alfonsi et al.}

collapsed elements, indicating an older age of the collapse with respect to the flowstone. At the chamber's junction, smaller and fragmented boulders form a pile sealed by flowstones (Figures 5b, 5c; zone 3 in Figure 3a), becoming the ramp leading to the second and deepest chamber. These main collapsed areas (zones 3 and 4 in Figure 3a) occur along the intersection of the structural lineaments recognized in the vault that, in conjunction with the bedding plane ( $255^{\circ}$ strike, dip $16-21^{\circ} \mathrm{NW}$ ), favored the ceiling vulnerability. Indeed, faults and joint orientations, along with bedding, are generally important in the development of the cave network [Ford and Ewers, 1978; Palmer, 1991]. The characteristics of the collapses as described above suggest a coseismic origin, and moreover we do not observe any elements that could associate this collapse to a gravitational phenomenon occurring in the cave or in the surroundings.

\subsection{Collapsed stalactites and severed stalactites/stalagmites}

There are many collapsed and severed elements, mostly concentrated at the junction of the two cave chambers (zone 2-3 in Figure 3a). Where the inferred faults merge (zone 2 in Figure 3a), a column element, the only one observed in the cave, shows evidence of damages (Figure 5d). The development of this pillar started on top of some blocks of the collapsed ceiling (see previous section).

In the first chamber, a large stalagmite, grown on top of one of the big collapsed blocks, is sharply broken (Figure 5e and zone 4 in Figure 3a). At least for those big and difficult to reach elements, including the ones observed in the ceiling, we exclude vandalism as the damaging cause. Broken curtain concretions are included in the collapsed limestone blocks and cemented by the draping flowstone (zone 3 in Figure 3a; Fig. 5c). Along the fault crossing the vault of the second chamber several large stalactites appear severed (Figures $4 \mathrm{~b}, 4 \mathrm{~d}$ and fault B in Figure 3a).

\subsection{Observation at the archaeological site}

The archaeological excavation is positioned behind the large collapsed area in the first chamber (zone 5 in Figure 3a). As described by Agostini et al. [1991], the stratigraphy exposed at the base of the trench walls is characterized by a well stratified fine deposit (Figure 6a), indicating an alluvial paleo-environment linked to fluvial transport and sedimentation occurring when the cave was still an active collector. We observed that this fine deposit borders the big collapsed boulders then, its deposition postdates the massive vault collapse (zone 4 in Figure 3a). The upper portion of the stratigraphy in the excavation includes a thin tabular flowstone (Figure 6a), and on top of it develops the archaeological settlement recognized by Agostini et al. [1991]. An upper flowstone overlays the whole sequence and forms the cave pavement (Figures 5a, 6a).

Suggestions for an additional younger collapse are observed in the excavation walls. These derive from the presence of several blocks and portions of the lower tabular concretion broken and sunk within the stratified laminated deposit (Figure 6b). In the fine deposit, we also observed perturbation of the layers typical of shaking occurrence in soft saturated sediment, i.e. seismites, and also the presence of brittle deformation and collapsed blocks (insets in Figures 6a, 6b). The upper portion of the section appears undisturbed. It is worth noting that this second inferred collapse is also mentioned by Agostini et al. [1991], although no further discussion is given.

\section{Radiocarbon dating for time constraints}

In order to provide a preliminary constraint for the age of the vault collapses at zone 4 and 3 of Figure 3a, we sampled organic soils and dated them with the ${ }^{14} \mathrm{C}$ radiocarbon method. All samples come from the first chamber (Figure 3a). The resulting samples ages are shown in Table 1, and are coherent with the relative stratigraphic position of the samples.

Sample BC07 belongs to the stratified fine deposit (Figures 6a, 6b), which deposition occurred after the large vault collapse since it seals undisturbed the big fallen boulders from the ceiling. The BC07 age of 30800-29700 BCE (Table 1) represents the minimum age for the collapse occurrence (i.e., postdates the collapse). Dating and stratigraphic analyses enhance that the huge vault collapse should be older than $30 \mathrm{kyr}$, with no further constraint given. 


\begin{tabular}{|c|c|c|c|c|c|c|}
\hline $\begin{array}{l}\text { Sample } \\
\text { code }\end{array}$ & Lab code & Sample Type & $\begin{array}{c}\delta^{13} \mathrm{C} \\
\text { (IRMS) }\end{array}$ & $\begin{array}{l}\text { Conventional Age } \\
\text { (before } 1950 \text { = B.P.) }\end{array}$ & $\begin{array}{l}\text { Calibrated Age } \\
\qquad(2 \sigma) \mathrm{cal}\end{array}$ & $\begin{array}{l}\text { Probability } \\
\text { Distribution }\end{array}$ \\
\hline BC03 & Beta - 497462 & Bulk & -26.3 & $6470+/-30$ & $5480-5370$ BCE & 0.954 \\
\hline BC04 & Beta - 499970 & Bulk & -25.2 & $6320 \pm 30$ & $5360-5220$ BCE & 0.954 \\
\hline ВC02 & Beta - 499971 & Bulk & -25.1 & $8370+/-30$ & $\begin{array}{l}7520-7420 \text { BCE } \\
7420-7360 \text { BCE }\end{array}$ & $\begin{array}{l}0.689 \\
0.311\end{array}$ \\
\hline ВC07 & Beta - 497463 & Bulk & -22.7 & $28320+/-140$ & $30800-29700$ BCE & 0.954 \\
\hline US1a* & & Carbonate & $\mathrm{np}$ & & $5530-5310$ BCE & 0.954 \\
\hline
\end{tabular}

*sample from Agostini et al., 2011

Table $1 .{ }^{14} \mathrm{C}$ dated samples from the Beatrice Cenci cave with conventional and calibrated ages (Beta Analytic Radiocarbon Dating Laboratory, Florida, USA; Reimer \& Reimer, R., 2009).

The age determination of samples BC02 and BC03 (Table 1) gives constraint for the hypothesized second collapse occurrence; the samples are respectively the soils below and above the lower tabular concretion (Figure 6a), whose breakage is associated with the second collapse. The resulting age interval for this second event occurrence would be 7360-5480 BCE. In support of this estimate, the radiocarbon ages of the soft sediments are in stratigraphic agreement with the age provided by Agostini et al. [2011], i.e. the age determination of the undeformed upper flowstone sampled in the terminal chamber (US1a, 5530-5310 BCE; Figure 3a and Table 1).

\section{Discussion and conclusion}

Several indicators point to evidence of a pervasive coseismic effect in the Beatrice Cenci cave, that occurred before 30ka, and caused the massive collapse of the vault, involving almost the whole first chamber. The collapsed boulders formed an about $10 \mathrm{~m}$ high ramp that gave rise to a difference in the topographic level between the first and second chambers of the cave (section in Figure 3a).

In our reconstruction, the collapse is coseismic and forced, in conjunction with other factors (i.e. regional uplift and fault slip), the decrease of the water flow that was progressively captured toward a lower stream base level. This gradual process acted in time to lift the former stream passage, the phreatic zone deepened and the cave entered with time in a vadose zone characterized by a more efficient concretional phase. This stage is linked to the formation of speleothems from water dripping from fissures and faults; this process likely took a decisive start after the huge collapse and uplift of the cave level. At this time, an ephemeral and seasonal water circulation was established, as also supported by the ceiling collapsed blocks that are not affected by the erosive action of high energy running waters. Moreover, the finely laminated sediment deposition, that surrounds the huge collapsed blocks of the vault, is typical of alluvial environments or pounds. The alluvial deposition was ongoing at least up to $\sim 9.5 \mathrm{kyr}$, that is the age of the sediments found right below the first tabular concretion (BC02 in Table 1). Then, the flowstone formation took place all around the cave, testifying a final dismissal of the alluvial environment within the cave chambers.

A difference in size and number of well-developed speleothems is observed between the initial and terminal chamber. Our hypothesis for the different development of the concretions is that, after the occurrence of the vault collapse in the first chamber, the dripping of the waters was concentrated on small fractures and/or bedding planes (fault A' in Figure 3a) mainly producing the flowstone draping the rocky blocks. While in the second chamber, the speleothems growth was guided by the continuous water dripping along the main faults elements (fault B in Figure 3a).

We do not have absolute dating of the large speleothems of the second chamber; thus, we cannot infer their time of deposition. However, some of the speleothems of great dimension in the second chamber are grown on top of the boulders of the collapsed ceiling (e.g., zone 2 in Figure 3a), then they would represent a post-vault collapse 


\section{Laura Alfonsi et al.}

deposition and their tilting took place later on. A rough time constraint for the large speleothems of the second chamber could find a possible support by the growth rate of speleothems furnished for caves in mid latitude humid regions [average rate $0.07 \mathrm{~mm} / \mathrm{yr}$; Baker et al., 1998; Tuccimei et al., 2003; Ferranti et al. 2019]. Roughly, if we consider this rate as a valid value for the Beatrice Cenci cave type, at least $30 \mathrm{kyr}$ are required to reach the speleothems present form, time congruent with the minimum age inferred for the event of the ceiling collapse.

In summary, we tentatively propose an evolution scheme of the Beatrice Cenci cave. A tectonic event along the Liri fault before 30 ka caused destruction in the cave and a huge vault collapse that involved the whole first cave chamber. In this phase, the cave underwent a hydrological change and the water stream found a new lower course. The destruction made by the shaking was particularly effective in this first chamber, almost completely occupied by collapsed blocks.
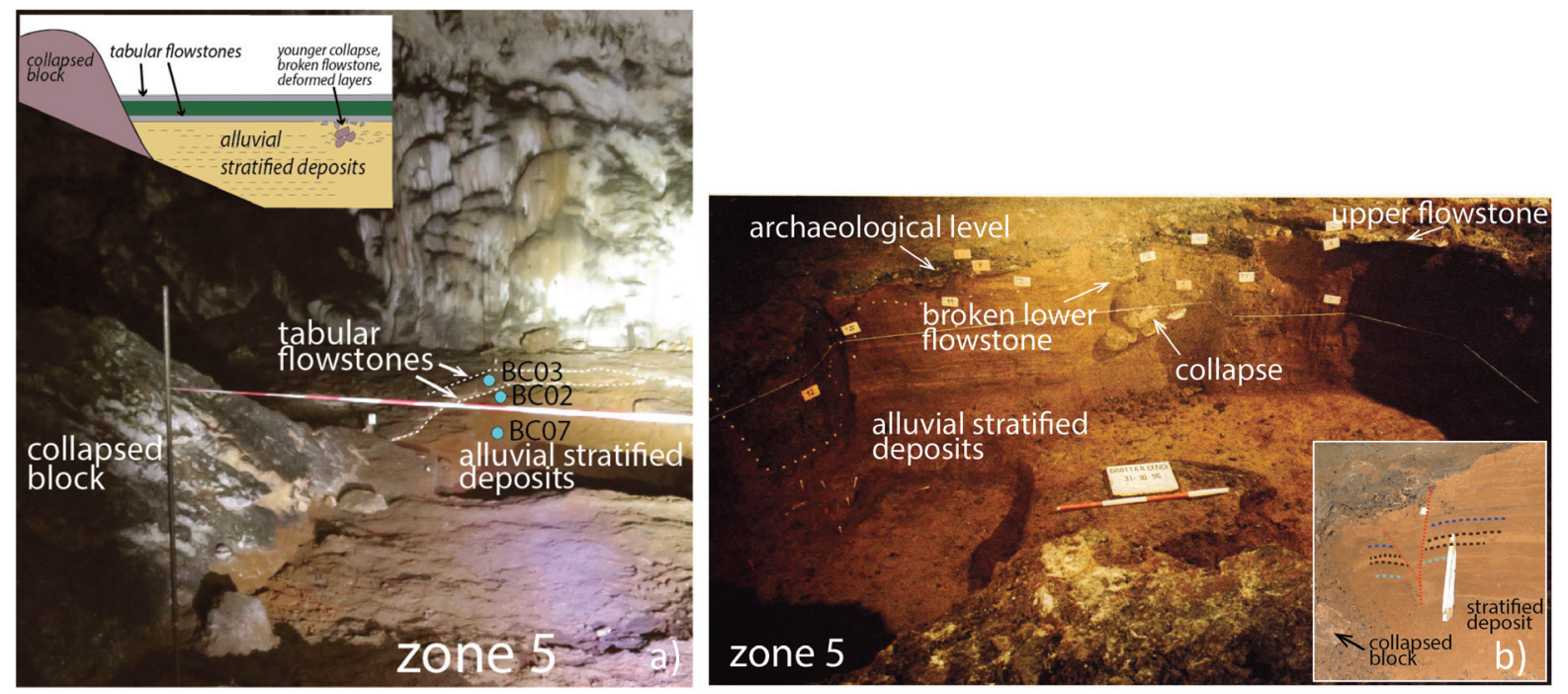

Figure 6. Observation at the archaeological site (zone 5 in Figure 3a): a) view of the two tabular flowstones and the underlying stratified alluvial deposits exposed in the excavation. Collected samples in light blue dots. The inset sketches the stratigraphy and the structures recognised; $b$ ) original photo of the archaeological excavation [from Agostini et al., 1991], on it are overimposed the interpreted stratigraphy and structures (this work). The inset to the right evidences the brittle deformations surveyed on the wall trench.

A probable second tectonic event between $7360 \mathrm{BCE}$ and $5480 \mathrm{BCE}$, caused another collapse again involving the first chamber. The main evidence is observed within the archaeological excavation, where together with the broken tabular older concretion, we observe collapsed blocks embedded within the soft sediment at different locations, seismites, and brittle fragile deformation. This tectonic event is likely the one that caused the tilting of the speleothems in the second chamber that, at the time of the second event occurrence, already have gained a considerable dimension. In this interpretation, the tilting of the speleothems would be an on-fault effect, caused by the activity of the Liri fault. Indeed, such deformation is generally interpreted as near fault-deformation [e.g. Forti and Postpischl, 1984].

We possibly observed part of the deformation induced by the activity of the fault crossing the cave (i.e. Liri fault), obviously this is not a complete history of earthquake damage within the cave. Indeed, besides the localized sampling, some damaging effects could have been hidden by human frequentation of the cave (construction of the pedestrian bench, vandalism etc.).

Finally, our preliminary data suggest that the northern portion of the Liri fault may be the causative fault of the recognized strong earthquakes, the oldest of which occurring before $30 \mathrm{kyr}$ and the youngest between 7360-5480 BCE. We do not have data that evidence damages younger than $7 \mathrm{kyr}$. This possibly reflects that the northern portion of the Liri fault did not produce large earthquakes in the recent time and/or that the Beatrice Cenci record could be incomplete and deserve further sampling to resolve the younger history of damage to the area. 
As already mentioned, the recent activity of the Liri fault is debated, and although there are no paleoseismological data on the fault that can be directly compared to the ages of events found in this work, some speleoseismological studies are available for nearby caves. The results obtained from Beatrice Cenci do not find correspondence with the record proposed for the Continenza cave [Giraudi and Frezzotti, 1999], $20 \mathrm{~km}$ to the West. While, the Pietrasecca cave, $\sim 16 \mathrm{~km} \mathrm{NW}$ of Beatrice Cenci, has recorded the effects from a strong earthquake at 30-40 kyr [Postpischl et al., 1991], possibly overlapping the age interval defined for the oldest paleoevent at Beatrice Cenci by this study. It is interesting the comparison of our data with those from Pace et al. [2020] in Grotta Cola, $\sim 2 \mathrm{Km}$ further East. The inferred youngest event in Beatrice Cenci cave (between 9-7.4 ka) could find an analogue in the Grotta Cola evidence. Pace et al. [2020], on the basis of different assumption, postgrowth hypothesis and comparison with paleoseismic data on different surrounding faults in the Grotta Cola region, set the age of a penultimate event around $\sim 5 \mathrm{ka}$ but, out of these indirect constraints, the broader interval obtained using the sample ages is between $\sim 7-14$ and $\sim 4-5 \mathrm{ka}$. Considering this time window, and also that the coseismic damage is found in caves located a few hundred meters apart along the same slope and both on-fault, a temporal coincidence for the past shaking in Grotta Cola and Beatrice Cenci is highly possible (at least for one of the events). Our results find correspondence in the model of seismic shaking from Grotta Cola [Pace et. al, 2020], suggesting the Liri fault as the most likely source responsible for the ground shaking recorded in the Grotta Cola cave, although it cannot be excluded a causative association of the speleoseismic damage with one among the potential seismogenic sources nearby.

Furthermore, the results of our study pointed out the influence of the Liri fault system on Mt. Aurunzo caves setting. As shown in Figure 3b, we infer that the northern section of the Liri fault is characterized by a $\sim 100 \mathrm{~m}$ wide-, $\sim 330^{\circ}$ $-340^{\circ}$ striking- zone, including at least three SW merging planes. The caves position relative to the Liri fault system is as follows: Grotta Cola in the footwall, Beatrice Cenci within the fault zone, and Ovito di Petrella and Imele swallow holes in the hanging wall. The actual dry entrances of the cavities have a higher altitude proceeding to Southeast (i.e. from Grotta Cola toward Ovito di Petrella; inset in Figure 1 and lower panel in Figure 3b). The Grotta Cola Cave is the older collector of the local endorheic fluvial basins and nowadays is at $\sim 240 \mathrm{~m}$ above the local river bed. This configuration of the caves points to a differential and progressive deepening of the active holes (at present the Ovito di Petrella) toward Northwest resulting from the uplift in time of the Liri fault footwall along the slope. We can state that the Liri fault activity influenced the evolution of the Beatrice Cenci and nearby cavities, and the settlement of the karst environment along the fault range of this sector of Mt. Carseolani.

Acknowledgements. The study was funded by the INGV project FISR2016 (Centro di studio e monitoraggio dei rischi naturali dell'Italia Centrale). A very special thanks has revolved to Mr. Alvaro and Corrado Frezzini for the access to the cave, for the collaborative exchanges, and for the fruitful discussions on the cave history. The paper was improved following reviews by L. Ferranti and an anonymous reviewer.

\section{References}

Agostini, S., S. Coubray, J. De Grossi Mazzorin, V. D’Ercole and E. Remotti (1991). Indagini preliminari nella Grotta Beatrice Cenci (L'Aquila), MiBAC Bollettino di Archeologia 8, 61-71.

Agostini, S., E. Di Canzion and M.A. Rossi (2011). Il rinvenimento di Ursus arctos di Grotta Beatrice Cenci (Cappadocia AQ) ed il significato paleoclimatico della successione del Pleistocene superiore finale - Olocene antico. Il Fucino e le aree limitrofe nell'antichità, Atti del III Convegno di Archeologia in ricordo di Walter Cianciusi, Castello Orsini, Avezzano, 13-15.

Baker, A., D. Genty, W. Dreybrodt, W. L. Barnes, N.J. Mockler and J. Grapes (1998). Testing theoretically predicted stalagmite growth rate with Recent annually laminated samples: Implications for past stalagmite deposition, Geochimica et Cosmochimica Acta, 62, 3, 393-404.

Becker, A., C.A. Davenport, U. Eichenberger, E. Gilli, P.Y. Jeannin and C. Lacave (2006). Speleoseismology: A critical perspective, J. Seismol., 10, 3, 371-388, doi:10.1007/s10950-006-9017-z.

Becker, A., P. Hauselman, J. Eikenberg, and E. Gilli (2012). Active tectonics and earthquake destructions in caves of northern and central Switzerland, Int. J. Speleology, 41, 1, 35-49.

Boni, C., P. Bono and G. Capelli (1988). Carta idrogeologica del territorio della Regione Lazio. Scala 1:250.000. 


\section{Laura Alfonsi et al.}

Pubblicazione Speciale Regione Lazio Vol. Unico. Roma: Regione Lazio (Italy).

Braun, Y., E. Kagan, M. Bar-Matthews, A. Ayalon and A. Agnon (2010). Dating speleoseismites near the dead sea transform and the Carmel fault: clues to coupling of a plate boundary and its branch, Israel J. Earth Sci., 58 , 257-273. http://dx.doi.org/10.1560/IJES.58.3-4.257.

Carrara, C., G. Dai Pra and C. Giraudi (1995). Lineamenti di tettonica plio-quaternaria dell'area, in "Lazio Meridionale, Sintesi delle Ricerche Geologiche Multidisciplinari”, ENEA Dipartimento Ambiente, Roma, 151155.

Chiarini, E., P. Messina and F. Papasodaro (1997). Evoluzione geologica e tettonica Plio Quaternaria dell'alta valle del F. Salto (Italia centrale). Primi risultati derivanti dall'analisi delle superfici relitte e dei depositi continentalìi, Il Quaternario, 10, 625-630.

Comerci, V., A.M. Blumetti, P. Di Manna, D. Fiorenza, L. Guerrieri, M. Lucarini, L. Serva., and E. Vittori (2013). ITHACA Project and capable faults in the Po Plain (northern Italy), Ingegneria Sismica, 1-2 January-June 2013, 36-45.

Compagnoni, B., M. D’Andrea, F. Galluzzo, M.C. Giovagnoli, P. Lembo, V. Molinari, and U. Chiocchini (2005). Illustrative notes of the geological map of Italy. Sheet 367, “Tagliacozzo”. Scale 1:50.000. Servizio Geologico d'Italia, Carta Geologica d'Italia.

Ciotoli, G., G. Etiope, S. Lombardi, N. Naso and M. Tallini (1993). Geological and soil-gas investigations for tectonic prospecting: preliminary results over the Val Roveto fault (Central Italy), Geologica Romana, 29, 483-493.

Fabbi, S., 2018. Geology of the eastern slopes of the Simbruini Mts. between Verrecchie and Capistrello (Central Apennines - Abruzzo, Italy), J. Maps, 14, 2, 435-446, doi:10.1080/17445647.2018.1483843.

Faure Walker, J.P., P. Boncio, B. Pace, G. Roberts, L. Benedetti, O. Scotti, F. Visini and L. Peruzza (2020). Fault2SHA central apennines database. London, United Kingdom: Institute for Risk and Disaster Reduction, University College London, PANGAEA, https://doi.org/10.1594/PANGAEA.922582.

Ferranti, L., B. Pace, A. Valentini, P. Montagna, E. Pons-Branchu, N. Tisnérat-Laborde, N. and L. Maschio (2019). Speleoseismological constraints on ground shaking threshold and seismogenic sources in the Pollino Range (Calabria, southern Italy), J. Geophys. Res.,124. https://doi.org/10.1029/2018JB017000

Ford, D.C. and R.O. Ewers (1978). The development of limestones cave system in the dimension of length and depth, Can. J. Earth. Sci., 15, 1783-1798.

Forti, P. and D. Postpischil (1984). Seismotectonic and paleoseismic analyses using karst sediments, Mar. Geol., 55, $145-161$.

Galadini, F. (1999). Pleistocene changes in the central Apennine fault kinematics: A key to decipher active tectonics in central Italy, Tectonics, 18, 5, 877-894.

Galadini, F. and P. Galli (2000). Active Tectonics in the Central Apennines (Italy) - Input Data for Seismic Hazard Assessment, Natural Hazards, 22, 2, 225-228.

Gavini, I.C. and G. Voltan (1892). Escursioni in Abruzzo. Annuario della Sezione di Roma del CAI, III, 1888-91, 71132.

Giraudi, C. and M. Frezzotti (1999). Segnalazione di stalattiti fratturate nella grotta-riparo Continenza di Trasacco: nuovi indizi di paleosismicità. In: S. Castenetto and F. Galadini (eds), 13 gennaio 1915: Il terremoto nella Marsica. Agenzia di Protezione Civile e Servizio Sismico Nazionale, Roma, 243-247.

Kagan, E.J., A. Agnon, M. Bar-Matthews and A. Ayalon (2005). Dating large infrequent earthquakes by damaged cave deposits, Geology, 33, 4, 261-264.

Kagan, E. J., F.R. Cinti, L. Alfonsi, R. Civico and M. Bar-Matthews (2017). Broken speleothems reveal Holocene and Late Pleistocene paleoearthquakes in Northern Calabria, Italy, Quat. Int., http://dx.doi.org/10.1016/j.quaint.2016.10.023.

Mecchia, G., M. Mecchia, M. Piro and M. Barbati (2003). Le grotte del Lazio. I fenomeni carsici, elementi della geodiversità, Collana Verde dei Parchi, Serie Tecnica n.3, Regione Lazio, http://www.parchilazio.it/pubblicazioni-55-le_grotte_del_lazio_i_fenomeni_carsici_elementi_della_geodiversita.

Montone, P. and F. Salvini (1993). Geologia strutturale dei rilievi tra Colli di Monte Bove (Carsoli) e Tagliacozzo, Abruzzo, Geologica Romana, 29, 15-29.

Pace, B., A. Valentini, L. Ferranti, M. Vasta, M. Vassallo, P. Montagna, A. Colella and E. Pons-Branchu (2020). A large paleoearthquake in the Central Apennines, Italy, recorded by the collapse of a cave speleothem, Tectonics, 39, e2020TC006289, https://doi.org/10.1029/2020TC006289.

Palmer A. (1991). Origin and morphology of limestone caves, Geol. Soc. Am. Bull., 103, 1-21. 
Papanikolaou, I.D., G.P. Roberts and A.M. Michetti (2005). Fault scarps and deformation rates in Lazio-Abruzzo, Central Italy: Comparison between geological fault slip-rate and GPS data Tectonophysics, 408, 147-176.

Postpischl, D., S. Agostini, P. Forti and Y. Quinif (1991). Paleoseismicity from karst sediments: the "Grotta del Cervo" cave case study (Central Italy). Tectonophysics, 193, 33-44.

Reimer, P.J. and R. Reimer (2009). CALIBomb radiation calibration, http://calib.org/CALIBomb/

Roberts, G.P. and A.M. Michetti (2004). Spatial and temporal variations in growth rates along active normal fault systems: an example from The Lazio-Abruzzo Apennines, central Italy, J. Struct. Geol., 26, 339-376.

Rovida A., M. Locati, R. Camassi, B. Lolli, P. Gasperini and A. Antonucci (eds), (2021). Italian Parametric Earthquake Catalogue (CPTI15), version 3.0. Istituto Nazionale di Geofisica e Vulcanologia (INGV), https://doi.org/10.13127/CPTI/CPTI15.3

Scotti., O., F. Visini., J. Faure Walker, L. Peruzza, B. Pace, L. Benedetti, P. Boncio and G. Roberts (2021). Which Fault Threatens Me Most? Bridging the Gap Between Geologic Data-Providers and Seismic Risk Practitioners, Front. Earth Sci., 8, 626401, doi: 10.3389/feart.2020.626401

Szczygieł, J., A. Sobczyk, H. Hercman, M.J. Mendecki and M. Gąsiorowski (2021). Damaged Speleothems and Collapsed Karst Chambers Indicate Paleoseismicity of the NE Bohemian Massif (Niedźwiedzia Cave, Poland), Tectonics, 40, 3, e2020TC006459, https://doi.org/10.1029/2020tc006459

Tuccimei, P., A. Borsato, P. Forti, S. Frisia, M. Paladini, L. Piccini, R. Salzano and U. Sauro (2003). Ricostruzione climatica dell'Olocene-Pleistocene superiore da una stalagmite del sistema carsico "Grotta del Fiume - Grotta Grande del Vento” (Gola di Frasassi, Ancona, Italia). Studi Trent. Sci. Nat., Acta Geologica, 80, 139-151. 